\title{
Methylation of selected CpG islands involved in the transcription of myeloperoxidase and superoxide dismutase 2 in neutrophils of periparturient and mid-lactation cows
}

\author{
Xanthippe Boulougouris, ${ }^{1}$ Carolien Rogiers, ${ }^{1}$ Mario Van Poucke, ${ }^{1}$ Bart De Spiegeleer, ${ }^{2}$ Luc Peelman, ${ }^{1}$ \\ Luc Duchateau, ${ }^{1}$ and Christian Burvenich ${ }^{1 *}$ \\ ${ }^{1}$ Animal Genetics Laboratory, Department of Nutrition, Genetics and Ethology, Faculty of Veterinary Medicine, Ghent University, Heidestraat 19, \\ Merelbeke, Belgium \\ ${ }^{2}$ Drug Quality and Registration (DruQuaR) group, Faculty of Pharmaceutical Sciences, Ghent University, Ottergemsesteenweg 460, Ghent, \\ Belgium
}

\section{ABSTRACT}

It is generally accepted that intracellular killing of microorganisms by production of reactive oxygen species (ROS) in the phagosome of the neutrophil is an important arm of innate defense. High-producing dairy cows are prone to periparturient metabolic and infectious diseases. Both myeloperoxidase (MPO) activity and ROS production decrease the day of parturition. Several studies have demonstrated changes in the expression of genes involved in, for example, metabolism and defense in the circulating neutrophil during peripartum. In this study, we wanted to further characterize the periparturient neutrophil in terms of its oxidative killing capacity by analyzing the oxidative burst at 3 levels. First, the ROS phenotype was evaluated using chemiluminescence. The cows (sampled within $24 \mathrm{~h}$ after parturition and at $135 \mathrm{~d}$ in milk) showed a significantly slower production of ROS at parturition. Both primiparous $(\mathrm{n}=13)$ and multiparous $(\mathrm{n}=12)$ cows were included in this study, but parity did not affect the kinetics of ROS production. Second, the expression of 11 genes involved in ROS production was measured in the same cows: cytochrome b-245 $\alpha$ and $\beta$ chain ( $C Y B A, C Y B B$; coding for membrane-bound constituents of NADPH oxidase); neutrophil cytosolic factors 1, 2, and 4 (NCF1, NCF2, and NCF4); Rac family small GTPase 1 and 2 (RAC1 and RAC2; coding for regulatory proteins of NADPH oxidase); superoxide dismutase 2 (SOD2); catalase (CAT); myeloperoxidase (MPO; coding for enzymes involved in metabolizing downstream ROS); and spleen-associated tyrosine kinase ( $S Y K$; involved in signaling). During peripartum, a shift in expression in the oxidative killing

Received November 21, 2018.

Accepted April 15, 2019.

*Corresponding author: christian.burvenich@ugent.be pathway was observed, characterized by a downregulation of $M P O$ and a simultaneous upregulation of the genes coding for NADPH oxidase. Third, as total DNA methylation is known to change during pregnancy, we investigated whether the observed differences were due to different methylation patterns. Promotor regions initiate transcription of particular genes; therefore, we analyzed the methylation status in annotated $\mathrm{CpG}$ islands of $M P O$ and SOD2, 2 genes with a significant difference in expression between both lactation stages. The differences in methylation of these $\mathrm{CpG}$ islands were nonsignificant. High-throughput techniques may be necessary to obtain more detailed information on the total DNA methylation dynamics in bovine neutrophils and increase our understanding of how gene expression is controlled in neutrophils.

Key words: peripartum, neutrophil, NADPH oxidase, myeloperoxidase

\section{INTRODUCTION}

Neutrophils can kill phagocytized microorganisms through the production of a wide range of reactive oxygen species (ROS; Kolaczkowska and Kubes, 2013). It has long been recognized that the bovine periparturient blood neutrophil function is altered, which predisposes the periparturient dairy cow to new infections (Kehrli et al., 1989). Heyneman et al. (1990) demonstrated a direct relationship between the capacity of this neutrophil to produce ROS and the subsequent clinical outcome of experimentally induced Escherichia coli mastitis. The clinical expression and complications of coliform mastitis around parturition vary remarkably, ranging from clinically severe to moderate and mild (Hill et al., 1979; Hill, 1981; Vandeputte-Van Messom et al., 1993). This is in sharp contrast with the more moderate clinical expression of coliform mastitis during established lactation (Burvenich et al., 1994; Shuster et al., 1996). There is also a tendency toward more 
severe clinical coliform mastitis cases in multiparous cows (Van Werven et al., 1997; Mehrzad et al., 2002; Vangroenweghe et al., 2004).

Analysis of gene expression in blood neutrophils from periparturient cows has revealed extensive changes that affect the immune status of the transition cow (Madsen et al., 2004; Burton et al., 2005; Crookenden et al., 2016). The bovine neutrophil proteome is also affected (Lippolis et al., 2006). Neutrophil gene expression can be controlled on an epigenetic level by DNA methylation, posttranslational modifications of histones, noncoding RNA, and nucleosome positioning along the DNA and genome instabilities (Jin et al., 2011; González-Recio et al., 2015).

The differential gene expression profiles between the periparturient period and mid lactation emphasize the importance of understanding how gene expression is controlled in neutrophils. Previous studies reported an inducible epigenetic regulation of gene expression in human mature neutrophils (Hellebrekers et al., 2018). Whole-DNA methylation studies in pregnant woman before and during pregnancy revealed time-dependent changes in methylation (Pauwels et al., 2017). Methylation of DNA is regarded as a key player in epigenetic silencing of transcription (Jin et al., 2011). Because particular hormonal and metabolic events seem to influence the inflammatory response of the bovine udder to $E$. coli infections during the periparturient period (Burvenich et al., 2007), it seems logical to hypothesize that the altered neutrophil ROS production during this period may be caused by altered epigenetic regulation of specific genes involved in the NADPH oxidase pathway and MPO.

In our research, we chose to focus on methylation of DNA to further elucidate the mechanism leading to an altered functional phenotype in periparturient cows. To achieve this, ROS regulation was studied at 3 different levels. The first level was its functional phenotype. Stevens et al. (2011) concluded that periparturient and established lactation neutrophil phenotypes, determined by measuring ROS production, are different. The second level was gene expression of NADPH oxidase, an enzyme comprising several regulatory proteins (Figure 1 ), and the expression of catalase $(C A T)$, myeloperoxidase $(M P O)$, and superoxide dismutase (SOD2). Once the NADPH oxidase is assembled and translocated to the membrane following activation (DeLeo et al., 1999), superoxide $\left(\mathrm{O}_{2}^{-}\right)$is generated, and these latter enzymes are involved in downstream metabolization of $\mathrm{O}_{2}^{-}$(Hurst, 2012). The third level was at the epigenetic level. Before gene expression, we checked for the occurrence of transcript variants in the target genes, but no alternative transcripts were found (results not shown). The methylation of selected $\mathrm{CpG}$ islands of 2 genes with a significant difference in expression between both lactation stages (SOD2 and MPO) was investigated.

\section{MATERIALS AND METHODS}

\section{Animal Selection and Blood Sampling}

Blood (50 mL) was collected (using EDTA-coated Vacutainer tubes; Becton Dickinson, Erembodegem, Belgium) from the coccygeal vein of 25 healthy Holstein-Friesian cows of the commercial dairy herd of Ghent University (Biocenter AgriVet, Melle, Belgium) at 2 time points: within $24 \mathrm{~h}$ postpartum and during mid lactation (135 \pm 7 DIM). The cows were selected based on the time the calf was expected, and sampling was spread over several months (January to November) to avoid seasonal influences on neutrophil function (Klink et al., 2012). Only cows that remained healthy between the 2 sampling periods were used, and their SCC per quarter at the time of sampling had to be below 200,000 cells/mL. All cows had calved normally and showed no clinical signs of periparturient diseases. Both primiparous $(\mathrm{n}=13)$ and multiparous $(\mathrm{n}=12)$ cows were incorporated in the study. The parity of the multiparous cows ranged from 2 to 5 . Blood was sampled between 0730 and $0830 \mathrm{~h}$ (before feeding) to minimize circadian influences on their functionality (Adrover et al., 2016). After collection, the blood tubes were gently inverted 3 times and immediately stored on ice. Blood was processed within 30 min after collection.

As mastitis can affect functionality of blood neutrophils (Mehrzad et al., 2001), aseptic quarter milk samples were collected at the time of blood sampling. For bacteriological cultures, $10 \mu \mathrm{L}$ of each milk sample was spread on blood-esculin (Oxoid, Basingstoke, UK) and MacConkey's agar (Oxoid) and incubated aerobically for 24 to $48 \mathrm{~h}$ at $37^{\circ} \mathrm{C}$. Bacteriological culture was performed according to National Mastitis Council (1999) guidelines. All quarters were free of major mastitis pathogens. In case of minor pathogens, only the samples that yielded polybacterial cultures and a low bacterial load were considered suitable for the study, as we assumed this reflected contamination during sampling. The study was approved by the Ethical Committee before beginning (number EC2014/11).

\section{Neutrophil Isolation and Stimulation}

Isolation of neutrophils was performed as described by Siemsen et al. (2007). The cells were handled with care to avoid activation. Purity of neutrophils was assessed by Diff-Quik staining (Microptic, Barcelona, Spain) using bright-field microscopy with a $100 \times$ objective and immersion oil (Axioskop 2 MOT, Carl Zeiss 
N.V., Oberkochen, Germany) by counting 100 cells in triplicate. Cell viability was determined by the Trypan blue (Invitrogen, Merelbeke, Belgium) exclusion test by counting 100 cells in triplicate. Purity of the cells was $97.35 \pm 0.89 \%$ and cell viability was $99.01 \pm 0.003 \%$. Fresh neutrophils $\left(2.5 \times 10^{6}\right)$ were used for chemiluminescence $(\mathbf{C L})$, and the remaining cells were aliquoted and stored immediately $\left(-80^{\circ} \mathrm{C}\right)$ until analysis of gene expression $\left(1 \times 10^{7}\right.$ cells $/ 200 \mu \mathrm{L}$ of PBS $)$ and DNA methylation $\left(5 \times 10^{6}\right.$ cells $/ 200 \mu \mathrm{L}$ of PBS $)$. The experimental design is depicted in Figure 2.

\section{Oxidative Burst Assay}

Immediately after isolation, neutrophils $\left(2.5 \times 10^{6}\right)$ were suspended in $120 \mu \mathrm{L}$ of Hanks' balanced salt solution without $\mathrm{Ca}^{2+}, \mathrm{Mg}^{2+}$, and phenol red (Thermo Fisher Scientific, Asse, Belgium) and challenged with either $100 \mathrm{ng} / \mathrm{mL}$ (final concentration) of phorbol myristate acetate (PMA; Sigma-Aldrich, Bornem, Belgium) or $1,000 \mu \mathrm{g} / \mathrm{mL}$ (final concentration) of opsonized Zymosan A (OZ; final volume: $200 \mu \mathrm{L}$, Sigma-Aldrich). In the control samples, stimulant was replaced by PBS (Invitrogen, Merelbeke, Belgium).
Zymosan A was opsonized by washing the pellet (250 $\mathrm{mg}$ ) twice with $240 \mathrm{~mL}$ of PBS (Invitrogen), followed by centrifugation at $200 \times g$ for $10 \mathrm{~min}$ at room temperature, $1 \mathrm{~h}$ of incubation at $37^{\circ} \mathrm{C}$ in $5 \mathrm{~mL}$ of PBS and $140 \mathrm{~mL}$ of bovine serum, and 2 additional washing steps in PBS (centrifugation at $200 \times g$ for $10 \mathrm{~min}$ at room temperature). Bovine serum was collected from the coccygeal vein of 3 healthy Holstein cows using 8-mL gel and clot activator tubes (Vacutest Kima, Arzergrande, Italy), and pooled before use. Luminol (Sigma-Aldrich) was added as a luminescent agent (final concentration of $0.3 \mathrm{mM}$ ), and CL was measured in quadruplicate at $37^{\circ} \mathrm{C}$ every $60 \mathrm{~s}$ for 90 min with a luminometer (TriStar $^{2}$ LB 942 Multidetection Microplate Reader, Berthold Technologies, Vilvoorde, Belgium) and expressed in relative light units. Different parameters of the ROS production were considered. Area under the curve (AUC), measured from the start up to the last time point, was used for the overall analysis. More specific responses of the ROS production used are the maximum height (MAX), the time to reach the maximum (TMAX), the rate of increase between the start and the maximum (slope), and the time from the maximum to reach half of the maximum $\left(\mathbf{T}_{\mathbf{1 / 2}}\right)$. The analysis is

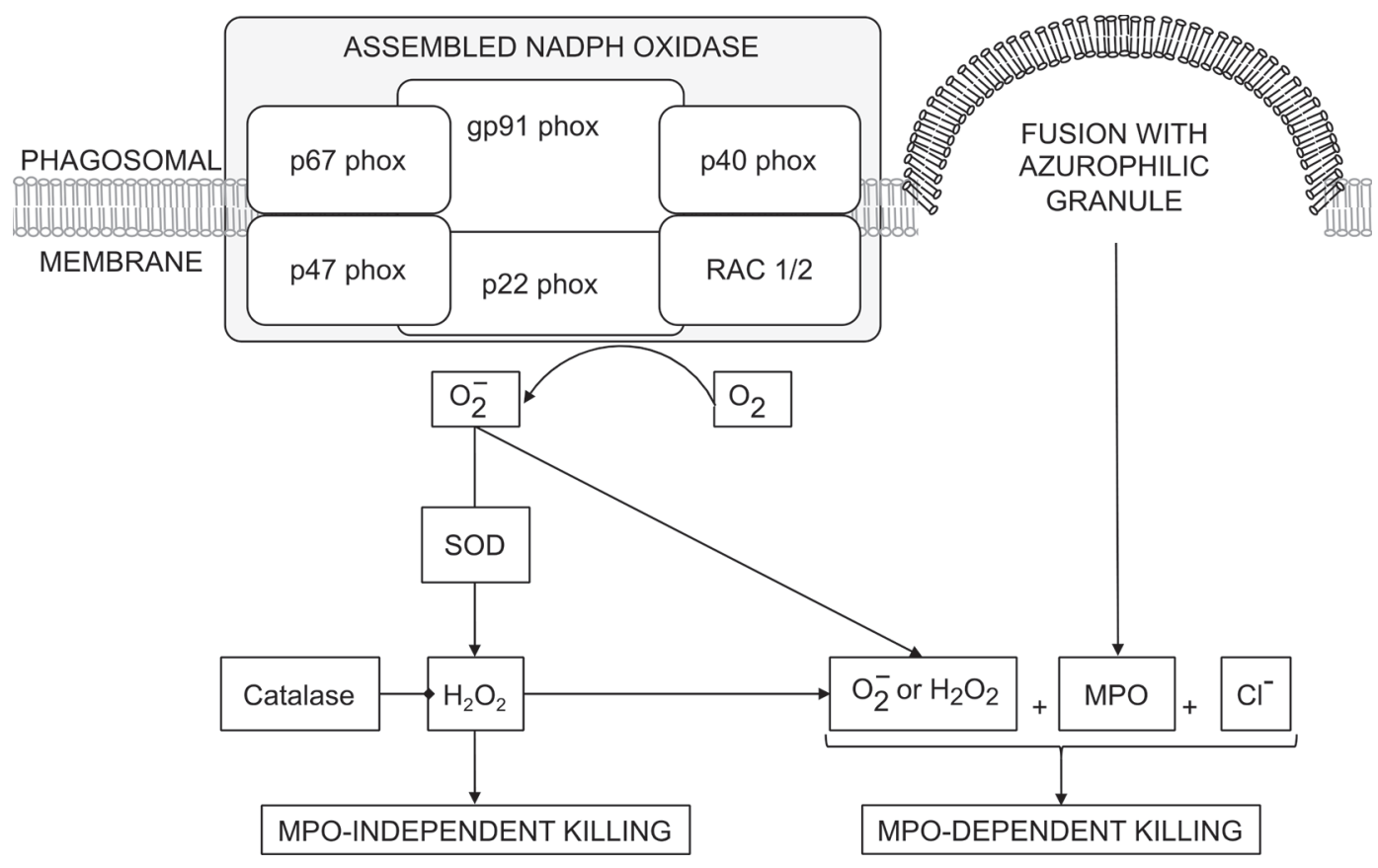

Figure 1. The major enzymatic steps responsible for the oxidative burst in neutrophils. (1) Myeloperoxidase (MPO)-independent killing. Flavocytochrome b558, comprising p22 phox (coded by $C Y B A$ ) and gp91 phox (coded by $C Y B B$ ), is the core component of NADPH oxidase (Decoursey and Ligeti, 2005). Upon activation, phosphorylation of p47 phox (coded by NCF1) induces its translocation to the membrane and the translocation of the other regulatory proteins [p67 phox (coded by NCF2), p40 phox (coded by NCF4), and Rac1/2 (coded by RAC1 and $R A C 2) ;$ Petry et al., 2010]. Once assembled, the NADPH oxidase complex is active, and superoxide $\left(\mathrm{O}_{2}{ }^{-}\right)$is generated. This is rapidly converted to hydrogen peroxide $\left(\mathrm{H}_{2} \mathrm{O}_{2}\right)$ either spontaneously or by enzymatic dismutation (by superoxide dismutase; SOD) and other downstream reactive oxygen species (Hurst, 2012). Catalase, another enzyme of the oxidative burst, is responsible for further breakdown of $\mathrm{H}_{2} \mathrm{O}_{2}$ to $\mathrm{H}_{2} \mathrm{O}$. (2) MPO-dependent killing. Granule-derived MPO catalyzes formation of $\mathrm{HOCl}$ from endogenous chloride and NADPH oxidase-derived superoxide or hydrogen peroxide (Hurst, 2012). 
based on the mixed model with cow as random effect and either parity or lactation stage as fixed effects.

\section{Target Genes}

A total of 11 target genes were selected on the basis of their potential role in decreased neutrophil ROS production around parturition: catalase $(C A T)$; cyto-

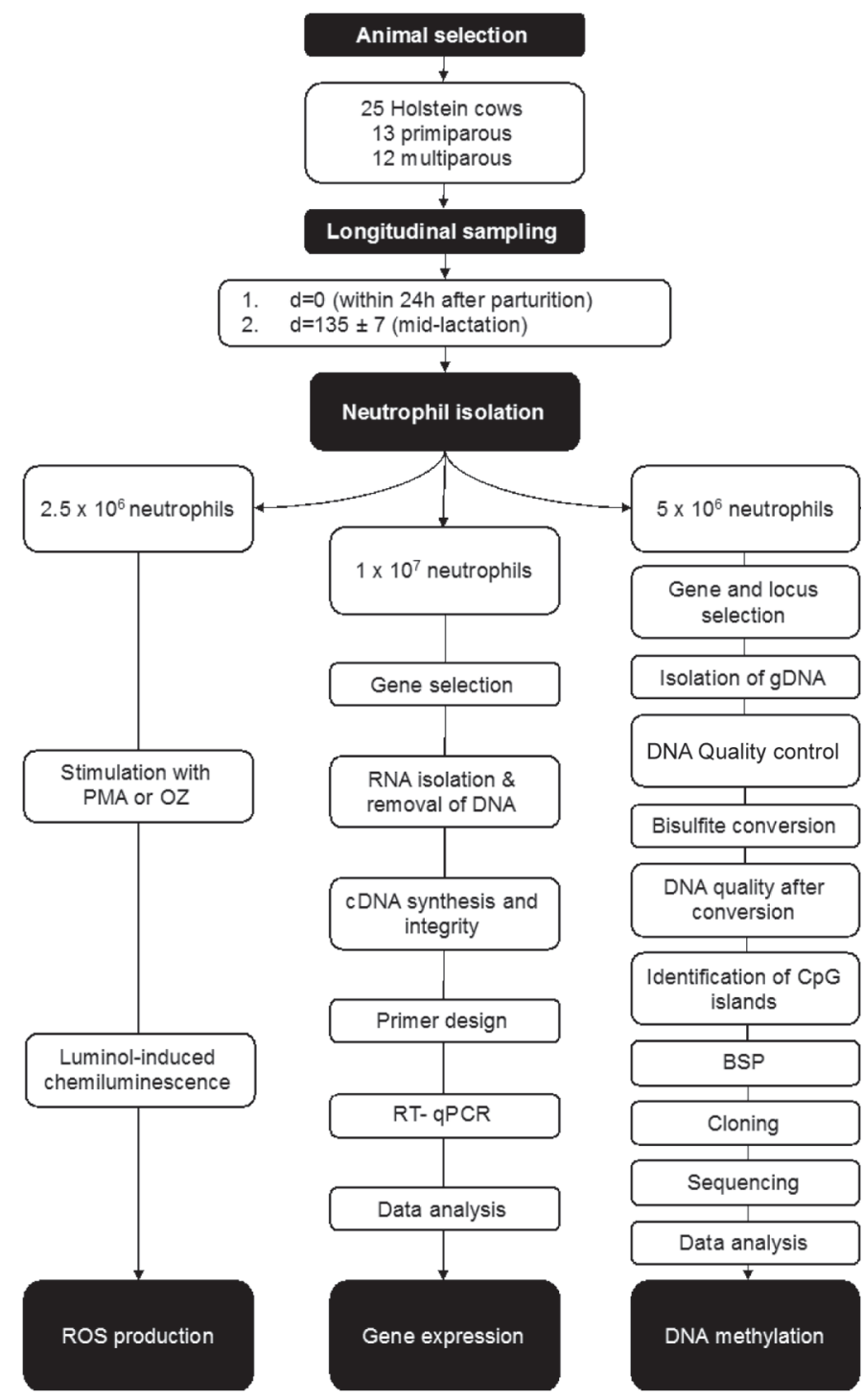

Figure 2. Experimental design. Blood was drawn from the coccygeal vein of 25 healthy dairy cows at the day of parturition (within $24 \mathrm{~h}$ after parturition) and $135 \pm 7 \mathrm{~d}$ postpartum. After isolation, the study consisted of 3 parts: (1) determination of reactive oxygen species (ROS) production by luminol-induced chemiluminescence, (2) gene expression profiling of a selection of genes related to the ROS pathway, and (3) determination of methylation status of $\mathrm{CpG}$ islands of 2 selected genes based on their pronounced difference in expression between the 2 lactation stages. PMA = phorbol myristate acetate; $\mathrm{OZ}=$ opsonized zymosan; RT-qPCR $=$ real-time quantitative $\mathrm{PCR}$; gDNA = genomic DNA; $\mathrm{BSP}=$ bisulfite sequencing PCR . chrome b-245 $\alpha$ and $\beta$ chain $(C Y B A, C Y B B)$; neutrophil cytosolic factors 1, 2, and 4 (NCF1, NCF2, and $N C F 4$ ); myeloperoxidase (MPO); Rac family small GTPase 1 and 2 (RAC1 and $R A C 2)$; superoxide dismutase 2 (SOD2); and spleen-associated tyrosine kinase (SYK; involved in signaling). The main biological functions of these genes are indicated in Supplemental Table S1 (https://doi.org/10.3168/jds.2018-16027).

\section{Total RNA Isolation and Removal of Contaminating DNA from RNA Samples}

To evaluate gene expression profiles, total RNA $(1 \times$ $10^{7}$ neutrophils) from all samples was extracted once all samples were collected using the Total RNA Isolation Reagent kit according to the manufacturer's protocol (Sigma-Aldrich). The obtained RNA was dissolved in $15 \mu \mathrm{L}$ of preheated $\left(65^{\circ} \mathrm{C}\right) 10 \mathrm{mM}$ Tris- $\mathrm{HCl}(\mathrm{pH} 8.0$; VWR International, Leuven, Belgium). Genomic DNA was removed by adding $4 \mu \mathrm{L}$ of RQ1 RNase-free DNase

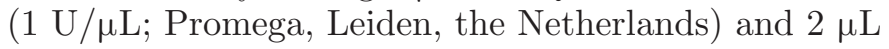
of $10 \times$ reaction buffer (Promega) to $14 \mu \mathrm{L}$ of RNA followed by incubation for $30 \mathrm{~min}$ at $37^{\circ} \mathrm{C}$. The reaction was terminated by adding $2 \mu \mathrm{L}$ of stop solution (Promega), and the RNA was purified by spin-column purification (Amicon Ultra 0.5-mL $100 \mathrm{~K}$ Centrifugal Filter, Merck Millipore, Brussels, Belgium). Absence of DNA in the samples was confirmed by minus reversetranscription PCR using HPRT1 primers as proposed by the MIQE guidelines (Integrated DNA Technologies, Leuven, Belgium; for primer sequence and conditions, see Supplemental Table S2; https://doi.org/10.3168/ jds.2018-16027). This was performed on the Eppendorf Mastercycler PCR system (Eppendorf, Rotselaar, Belgium). A PCR mix was made in a total volume of $10 \mu \mathrm{L}$ per sample, containing $1 \mu \mathrm{L}$ of template (RNA, genomic DNA as positive control, and water as negative control), $0.1 \mu \mathrm{L}$ of Taq DNA Polymerase $(5 \mathrm{U} / \mu \mathrm{L}$; Roche Applied Science, Vilvoorde, Belgium), $0.2 \mu \mathrm{L}$ of dNTP Mix (10 mM each; Bioline, London, UK), $1 \mu \mathrm{L}$ of HPRT1 primers (forward and reverse, $2 \mu M$ each; Integrated DNA Technologies), $1 \mu \mathrm{L}$ of $10 \times$ FastStart Taq DNA Polymerase Buffer (Roche Applied Science), and $6.7 \mu \mathrm{L}$ of ultrapure water (Milli-Q, Merck Millipore). The PCR program consisted of an initiation step of $4 \mathrm{~min}$ at $95^{\circ} \mathrm{C}$ followed by 40 amplification cycles [denaturation for $15 \mathrm{~s}$ at $95^{\circ} \mathrm{C}$, annealing for $15 \mathrm{~s}$ at $62^{\circ} \mathrm{C}$ (Supplemental Table S2; https://doi.org/10.3168/ jds.2018-16027), and extension for $30 \mathrm{~s}$ at $\left.72^{\circ} \mathrm{C}\right]$ and a final 2-min elongation step at $72^{\circ} \mathrm{C}$. The amplification products were analyzed on a $2 \%$ ethidium bromidestained agarose gel (135 V, 25 min; results not shown), and DNase treatment was repeated if DNA was still present. 
Purity and concentration of the samples were measured with a Nanodrop ND-1000 Spectrophotometer (Isogen Life Science, Sint-Pieters-Leeuw, the Netherlands), and the mean concentration was $90 \mathrm{ng} / \mu \mathrm{L}$. The RNA integrity was assessed an Experion Automated Electrophoresis system (Bio-Rad, Hercules, CA) using High Sense chips. The average RNA quality index value of RNA from neutrophils was $8 \pm 0.88$, which indicates that the quality is good (Riedmaier et al., 2010). Samples were stored at $-20^{\circ} \mathrm{C}$ until cDNA synthesis.

\section{cDNA Synthesis and cDNA Integrity}

Ten microliters of DNA-free total RNA (on average $900 \mathrm{ng}$ ) was immediately converted to cDNA using random hexamers and oligo dT primers (each $0.5 \mu \mathrm{g} /$ reaction) by means of the Improm-II Reverse Transcription System (Promega).

To check cDNA integrity for the real-time quantitative PCR (RT-qPCR) experiment, a YWHAZ (tyrosine 3-monooxygenase/tryptophan 5-monooxygenase activation protein, zeta) primer assay was used as described by Verbeke et al. (2015). This assay comprises 1 forward primer and 3 reverse primers that can amplify amplicons of 109, 497, and 909 bp, respectively.

\section{$R T-q P C R$ of Target and Reference Genes}

Primer Design for RT-qPCR Assay. Primers were designed using Primer3Plus software (Untergasser et al., 2007). A list of the target and housekeeping genes and primer conditions is shown in Supplemental Table S2 (https://doi.org/10.3168/jds.2018-16027). The target and housekeeping gene RT-qPCR was performed in duplicate by SYBR Green chemistry (SYBR Green PCR Master Mix; Applied Biosystems, Asse, Belgium). The increase in fluorescence of the SYBR Green dye was monitored using an iCycler (Applied Biosystems). During each run, a no-template control and a standard curve of serial dilution points were included (5 dilution points) to create a standard curve and perform PCR efficiency calculations. The PCR efficiencies were between 98 and $103.5 \%$. The cycling conditions comprised polymerase activation at $95^{\circ} \mathrm{C}(3 \mathrm{~min})$ and 40 cycles of amplification (denaturation at $95^{\circ} \mathrm{C}$ for $3 \mathrm{~s}$, annealing and elongation at an assay-specific temperature for 30 $\mathrm{s}$, followed by the detection of the generated fluorescent signal). Absence of primer dimers was verified by melting curve analysis $\left(75-90^{\circ} \mathrm{C}\right.$ per $0.3^{\circ} \mathrm{C}$ increment) and were absent in all reactions.

Gene Expression Measurement and Data Analysis. Cycle threshold values and raw expression data were determined for the reference and target genes on all samples. Six candidate reference genes (ACTB, B2M, G6PD, H2A, HPRT1, and YWHAZ) were selected based on previous research (Goossens et al., 2005; Stevens et al., 2011), as encouraged by the MIQE guidelines (Bustin et al., 2009). Obtained relative quantities, calculated based on the delta-delta-Ct method taking into account qPCR efficiencies (Pfaffl, 2001), were normalized using the geometric mean of the 4 most stable reference genes (G6PD, H2A, HPRT1, and YWHAZ; Supplemental Table S2, https://doi.org/ 10.3168/jds.2018-16027; Vandesompele et al., 2002). For all statistical analysis, these normalized expression data were converted to logarithmic (base 10) values to make the data distribution symmetrical and to obtain more accurate and relevant results (Hellemans and Vandesompele, 2011). The pairwise variation (V3/4) of these genes using geNorm (https://genorm.cmgg .be) was 0.208; therefore, they were deemed suitable as internal control. The analysis for difference in gene expressions between the 2 lactation stages was based on the signed rank test using cow as blocking factor.

\section{Analysis of Methylation Status of MPO and SOD2 CpG Islands}

The gene expression profiles showed that SOD2 had the highest increase in expression in primiparous cows, whereas the highest decrease was found for $M P O$. We selected these genes to further investigate the mechanism behind this differential expression. We optimized a strategy for cloning-based locus-specific sequencing PCR. With this, we investigated the methylation status of specific $\mathrm{CpG}$ islands at single base resolution. As this method is described elsewhere, including the strategies for quality control assessment, it is not covered in detail here (Van Poucke et al., 2017).

DNA Isolation. For the analysis of methylation status of the genes of interest, one part of the isolated neutrophils $\left(5 \times 10^{6}\right.$ neutrophils $)$ was resuspended in $200 \mu \mathrm{L}$ of PBS (as mentioned above) and stored immediately at $-80^{\circ} \mathrm{C}$. The DNA was isolated with the Quick-DNA Miniprep Plus Kit (including a proteinase $\mathrm{K}$ digest) according to the manufacturer's protocol (Zymo Research, Freiburg, Germany).

DNA Quality Control Before Bisulfite Conversion. Concentration and purity of the DNA were measured with a Nanodrop ND-1000 Spectrophotometer (Isogen Life Science). The mean concentration was $200 \mathrm{ng} / \mu \mathrm{L}$ with a purity of optical density $260 / 280=$ 1.9. Integrity of the DNA was evaluated by performing the ubiquitin C integrity test (Van Poucke and Peelman, 2017). The results on the gel showed generation of all amplicons. We thus considered our DNA to be pure and of good quality. 
Bisulfite Conversion and DNA Quality Control After Conversion. Bisulfite conversion was performed on $500 \mathrm{ng}$ of RNA-free high-quality DNA with the EZ DNA Methylation-Lightning Kit (Zymo Research) according to the manufacturer's recommendations. The bisulfite-converted DNA was eluted in 10 $\mu \mathrm{L}$, resulting in around $40 \mathrm{ng} / \mu \mathrm{L}$ of bisulfite-converted DNA. As bisulfite conversion is known to damage DNA, we assessed quantity and purity after conversion. The ubiquitin $\mathrm{C}$ bisulfite integrity assay was performed on $5 \mathrm{ng}$ of bisulfite-converted DNA, and the integrity was considered excellent after conversion (described by Van Poucke et al., 2017). Bisulfite-converted DNA was aliquoted and stored immediately at $-20^{\circ} \mathrm{C}$.

In Silico Identification of CpG Islands and Primer Design. In silico identification of CpG islands of $M P O$ and SOD2 was assessed using different genome browsers [UCSC Genome Browser (Kent et al., 2002), Ensemble (Yates et al., 2016), and NCBI (https://www .ncbi.nlm.nih.gov/)] and online tools [CpG Islands, The Sequence Manipulation Suite (Stothard, 2000), DBCAT (Kuo et al., 2011), CpGplot (EMBOSS; https:/ /www.ebi.ac.uk/Tools/seqstats/emboss_cpgplot/), and MethPrimer (Li and Tollefsbol, 2011)]. Based on common hits, we chose the most important region for each gene to investigate further. For SOD2, it consists of a region in the promotor region. For $M P O$, we chose an intragenic region comprising exon 4 and 5. A detailed description of the selected regions is found in Table 1.

Methylation-independent bisulfite sequencing PCR primers were designed as described by Van Poucke et al. (2017). Amplicon length was based on the length of the $\mathrm{CpG}$ islands of interest and the integrity and amplificability of the bisulfite-converted DNA. A list of the loci and primer conditions are shown in Supplemental Table S3 (https://doi.org/10.3168/jds.2018-16027).

Methylation-Independent Bisulfite Sequencing PCR. The PCR was performed using TEMPase HotStart polymerase (VWR, Leuven, Belgium). The protocol consisted of an initiation step at $95^{\circ} \mathrm{C}$ for 14 min $30 \mathrm{~s}$ and 40 cycles $\left(30 \mathrm{~s}\right.$ at $95^{\circ} \mathrm{C}, 30 \mathrm{~s}$ at annealing temperature, $2 \mathrm{~min}$ at $72^{\circ} \mathrm{C}$ ) with $5 \mathrm{ng}$ of bisulfite- converted DNA as a template on an S1000 Thermal Cycler (Bio-Rad) with gradient function. The optimal annealing temperature was determined experimentally by a 5 -point gradient PCR.

Cloning Strategy. After bisulfite conversion, fragments were analyzed using a pooled cloning strategy in pCRII (TA Cloning Kit, Invitrogen) as described by Van Poucke et al. (2017). Four and 3 different amplicons were eluted together with the Geneclean II kit (MP Biomedicals, Illkirch, France) and cloned in pCRII. Colony PCR (10 $\mu \mathrm{L}$ total volume) with the pCRII primer assay was used to identify the insert of the individual colonies based on their fragment length on gel $(2 \mu \mathrm{L})$.

Sequencing. The rest of the colony PCR product $(8 \mu \mathrm{L})$ of the selected clones (we used 6 clones for every fragment) was cleaned up for Sanger sequencing by adding $4 \mathrm{U}$ of exonuclease I (Bioké, Leiden, the Netherlands) and $2 \mathrm{U}$ of antarctic phosphatase (Bioké). It was then incubated for $30 \mathrm{~min}$ at $37^{\circ} \mathrm{C}$ to allow an enzymatic reaction followed by $15 \mathrm{~min}$ at $80^{\circ} \mathrm{C}$ for enzyme inactivation. Two microliters of the treated PCR product was used for the sequencing reaction, with both PCR primers as individual sequencing primer as described above.

Data Analysis. The sequencing chromatograms were inspected manually for errors and the sequences were trimmed to obtain the insert without ampliconspecific primer sequences with BioEdit (Hall, 1999). Extraction of the methylation data (including quality control by aligning with the reference sequence and visualization of the single methylation spots) was performed with Bisma (http://services.ibc.uni-stuttgart .de/BDPC/BISMA/index.php). We first calculated the mean methylation per primer per cow per lactation stage. For each primer, the 2 lactation stages were compared using a paired $t$-test with cow as a blocking factor.

PCR Bias Control. Due to PCR bias, methylated and unmethylated sequences might not be proportionately amplified. It is, however, important to ensure that methylated and unmethylated sequences are propor-

Table 1. Characteristics of CpG islands of 2 selected genes used for analysis of methylation in this study

\begin{tabular}{lcc}
\hline Item & MPO & SOD2 \\
\hline NCBI $^{1}$ accession no. & NC_037346.1 & NC_037336.1 \\
Position & Chr19:9482319-9482919 & Chr9:97398487-97399971 \\
Genomic size (bp) & 601 & 1,485 \\
CpG count & 53 & 174 \\
C count plus G count & 418 & 1,042 \\
Percentage CpG & 17.6 & 23.4 \\
Percentage C or G & 69.6 & 70.2 \\
Ratio of observed to expected CpG & 0.73 & 0.95 \\
\hline
\end{tabular}

${ }^{1}$ National Center for Biotechnology Information. 
Table 2. Kinetics of reactive oxygen species production in periparturient and mid-lactation cows after stimulation with opsonized zymosan (OZ; SEM in parentheses) and phorbol myristate acetate (PMA; SE in parentheses) ${ }^{1}$

\begin{tabular}{lcccr}
\hline Item & AUC & MAX & TMAX $^{4}$ & SLOPE $^{5}$ \\
\hline OZ & & & & \\
Parturient & $21,713(1,647.91)$ & $39,561.00(3,550.83)$ & $31.19(1.78)$ & $1,523.05(226.92)$ \\
Mid-lactation & $21,913(1,647.91)$ & $47,743.00(3,624.06)$ & $18.22(1.81)$ & $2,856.03(231.60)$ \\
PMA & & & & $37.88(1.84)$ \\
Parturient & $11,412(496.83)$ & $53,416.00(4,551.14)$ & $6.10(0.21)$ & $9,438.46(982.02)$ \\
Mid-lactation & $10,704(496.83)$ & $61,004.00(4,551.14)$ & $5.50(0.21)$ & $11,399.00(982.02)$ \\
\hline
\end{tabular}

${ }^{1}$ The analyses are based on the mixed model with cow as random effect and either parity or lactation stage as fixed effects factor.

${ }^{2}$ Area under the curve (relative light units $\times \mathrm{s}$ ).

${ }^{3}$ Maximum height (relative light units).

${ }^{4}$ Time to reach the maximum (min).

${ }^{5}$ Rate of increase in production between the start and the maximum.

${ }^{6}$ Time from the maximum to reach half of the maximum (min).

tionately amplified to obtain reliable results (Wojdacz et al., 2008). New methylation-independent native DNA primers for both $M P O$ and SOD2 were designed as described above to perform PCR (Supplemental Table S4; https://doi.org/10.3168/jds.2018-16027). The resulting amplicons were aliquoted: one part (50\%) served as the nonmethylated part, and the remaining part was methylated by SssI methyltransferase (New England Biolabs, Hitchin, UK). An aliquot of both parts was incubated overnight with the restriction enzyme $\mathrm{HpaII}$ (New England Biolabs). The intact methylated part and restricted nonmethylated part were confirmed by gel electrophoresis. Another aliquot of both parts was put together and purified with a QIAquick PCR Purification Kit (Quigen, Hilden, Germany). All bisulfite sequencing assays were performed after bisulfite conversion as described above. The resulting amplicons were restricted with TaqI (New England Biolabs) to check for PCR bias and with HpaII to check bisulfite conversion. Restriction was checked by gel electrophoresis and revealed that TaqI restricted $50 \%$ of the amplicons, indicating the absence of PCR bias, and HpaII was not able to restrict any of the amplicons, indicating a successful bisulfite conversion.

\section{RESULTS}

\section{Neutrophil Phenotype}

Based on the AUC, unstimulated cells from cows just after calving demonstrated less $(P<0.0001)$ luminoldependent CL compared with cows from mid lactation (results not shown). There were no significant differences in the AUC in the luminol-dependent CL between primiparous and multiparous cows $(P=0.7438)$. Parity had no significant effect on the CL response (results not shown).

Neutrophils from periparturient and mid-lactation cows demonstrated a similar AUC after stimulation with PMA. The MAX and slope did not reveal significant differences between the 2 lactation stages. The TMAX was significant longer $(P=0.0371)$ in neutrophils obtained from cows just after calving $(5.5 \mathrm{~min})$ compared with mid-lactation cows (6.10 min). Finally, $\mathrm{T}_{1 / 2}$ was longer $(P=0.0141)$ in periparturient cows (9.30 min) than in mid-lactation cows (7.04 min; Table 2 ). We found no effect of parity for the kinetics of ROS production.

Neutrophils from periparturient and mid-lactation cows demonstrated a similar AUC after 90 min of stimulation with OZ. As expected, CL increased more slowly after OZ stimulation compared with PMA (Lieberman et al., 1996). The time to reach MAX and the slope were significantly different between both lactation stages. Neutrophils obtained from periparturient cows needed more time $(31.19 \mathrm{~min} ; P<0.0001)$ to reach MAX compared with the mid-lactation group (18.22 $\min )$, and the slope $(P=0.0002)$ to reach MAX was less steep in periparturient cows. In addition, $\mathrm{T}_{1 / 2}$ was higher $(P=0.0003)$ in periparturient cows $(37.88 \mathrm{~min})$ than in mid-lactation cows (28.47 min; Table 2; Figure $3 \mathrm{~A})$. We found no effect of parity for the kinetics of ROS production (Figure 3B).

\section{Neutrophil Genotype}

Effect of Parturition on the ROS-Pathway Transcriptome. Shortly after parturition, neutrophils showed an increase in transcription of mRNA from several genes encoding regulatory proteins involved in activation of NADPH oxidase, as seen in an upregulation of NCF1 $(P=0.0002), N C F 4(P=0.0002), R A C 1$ $(P<0.0001)$, and RAC2 $(P=0.0020)$. Expression of CYBA $(P=0.0014)$ and SOD2 $(P<0.0001)$ was also increased within $24 \mathrm{~h}$ after parturition compared with mid lactation (Figure 4). Interestingly, $M P O(P=$ $0.0340)$ showed a significantly lower expression within 

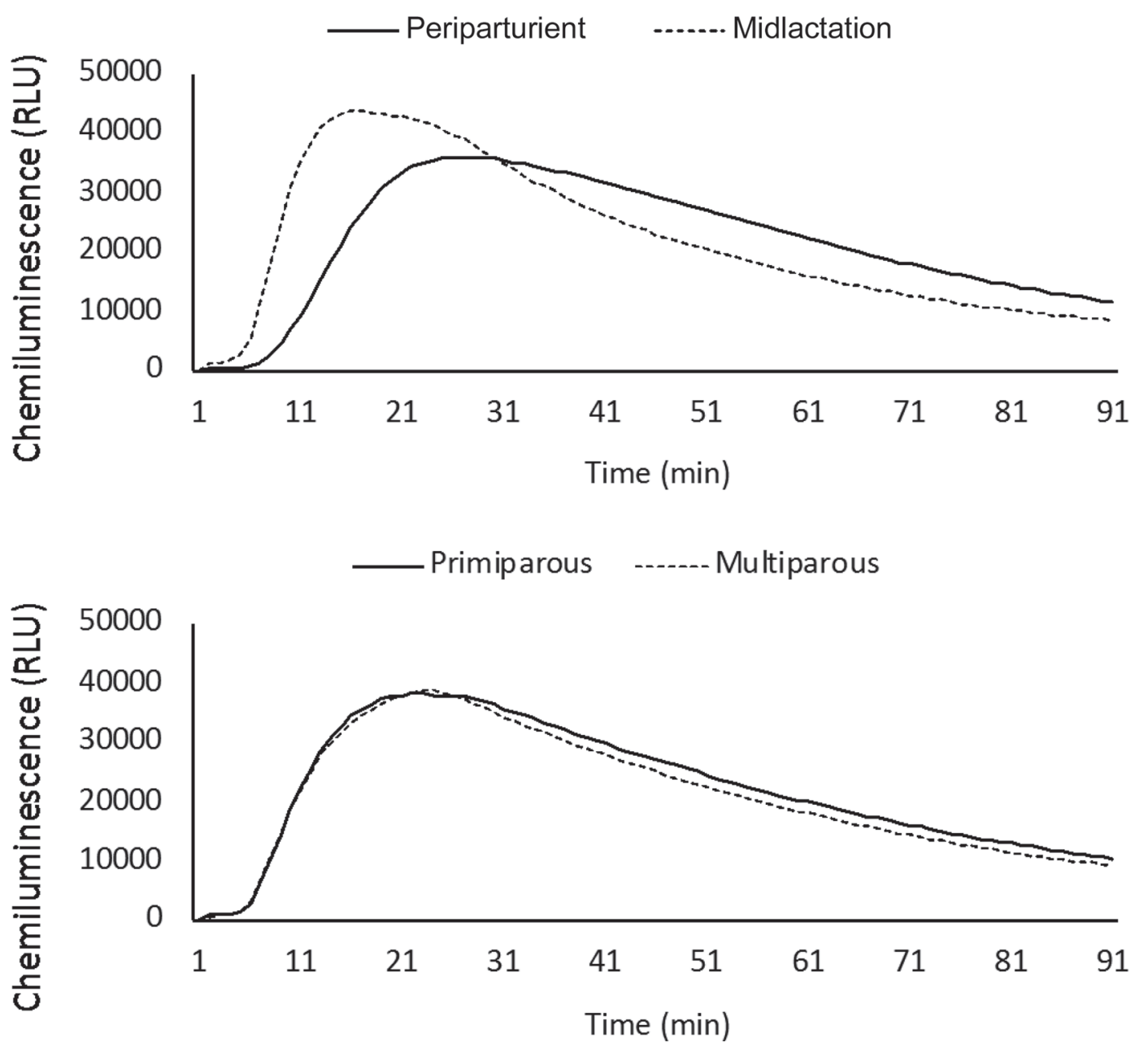

Figure 3. Luminol-induced chemiluminescence of periparturient and mid-lactation bovine neutrophils isolated from primiparous and multiparous cows after stimulation with opsonized zymosan. (A) Effect of lactation stage. (B) Effect of parity. Chemiluminescence was measured every $60 \mathrm{~s}$ for $90 \mathrm{~min}$ and expressed in relative light units (RLU). Lines represent means of all data.

$24 \mathrm{~h}$ after parturition; $C A T$ was also downregulated $(P$ $=0.0002 ;$ Figure 4$)$. No statistically significant effect of parturition versus mid lactation could be demonstrated for $C Y B B, S Y K$, and NCF2.

Mean Fold Gene Expression Between Parturient and Mid-Lactation Cows. Mean fold expression differences between the 2 lactation stages were calculated to estimate the potential importance of each target gene in the decreased ROS production seen in periparturient cows. Expression of SOD2 was almost 3 times higher (expression ratio periparturient/mid lactation $=2.98)$ in parturient cows, whereas $M P O$ expression was more than 2 times lower (expression ratio periparturient $/ \mathrm{mid}$ lactation $=-2.12$ ) in periparturient cows (Figure 5; Table 3).

Correlation Between OZ-Induced ROS Production and ROS Gene Expression Profiles. The spearman correlation coefficients between the relative expression profiles and TMAX after OZ stimulation were calculated, and the significance of these correlations is listed in Table 3. Based on these results and their biological relevance, we chose $M P O$ and SOD2 as the target genes to further investigate the methylation status.

\section{Neutrophil Epigenotype}

The mean methylation status of the different primers revealed no significant differences between lactation stages. However, we found some differences in methylation at the individual $\mathrm{CpG}$ sites. Because this might contain interesting information, the percentages of methylation of the individual methylation loci are given in Figure 6. 


\section{DISCUSSION}

Defects in the ability of neutrophils to generate ROS are associated with impaired capacity to clear pathogens (Dupré-Crochet et al., 2013). The current study investigated lactation stage-dependent effects on bovine neutrophil oxidative burst activity at 3 levels. More specifically, we evaluated the kinetics of ROS production, gene expression of 11 target genes involved in the oxidative burst, and the methylation status of 2 selected $\mathrm{CpG}$ islands possibly involved in the epigenetic regulation of $M P O$ and SOD2, 2 key genes in the neutrophil oxidative burst pathway.

At the phenotypic level, stimulation with PMA revealed significant differences between the 2 lactation stages, with an earlier peak in neutrophils obtained from mid-lactation cows (MAX) and a prolonged production $\left(\mathrm{T}_{1 / 2}\right)$ in neutrophils obtained from periparturient cows. We found no effect of parity on the kinetics of ROS production after stimulation with PMA. Phorbol myristate acetate is a membrane-permeable compound, and it strongly induces phosphorylation of the regulatory proteins and subsequent NADPH oxidase assembly (El-Benna et al., 2009). Other stimuli, such as OZ, are mediated by receptors and only lead to partial phosphorylation of the regulatory proteins (Petry et al., 2010), which takes more time to generate a response. Possibly, part of the differences in the ability to produce ROS (AUC) between the 2 lactation stages are masked due to the strong activation potential of PMA. Results of our unstimulated cells confirmed that there is indeed a difference in the capacity to produce ROS between the 2 lactation stages, as measured by the AUC (results not shown). Depending on the applied trigger, periparturient neutrophils are capable, albeit slightly delayed, of producing a similar amount of ROS as in mid lactation. This can be interesting because priming the neutrophils with powerful mediators might offer therapeutic possibilities. However, the delay in ROS production is intriguing because it becomes more pronounced after stimulation with OZ, and this thus might reflect differences in receptor-dependent activation. After stimulation with OZ, we could not find any difference in the total ROS production between the 2 lactation stages, as indicated by the AUC (Figure 3A). Typically, in other CL studies where zymosan was used as a stimulus, a decreased AUC was reported during the first week after calving (Hoeben et al., 2000; Mehrzad et al., 2002); however, the opposite has also been stated, with an increase of AUC (Rinaldi et al., 2008). However, neutrophils from mid-lactating cows showed a significantly shorter time needed to reach MAX after stimulation with OZ in our study. This effect was independent of parity (Figure 3B). In addition, the slope of the mid-lactating group were significantly steeper before reaching MAX and $\mathrm{T}_{1 / 2}$ was lower. This indicates a more robust production of ROS in mid-lactation cows. The periparturient cows, in contrast, showed a slower

\section{- Parturition Mid lactation}

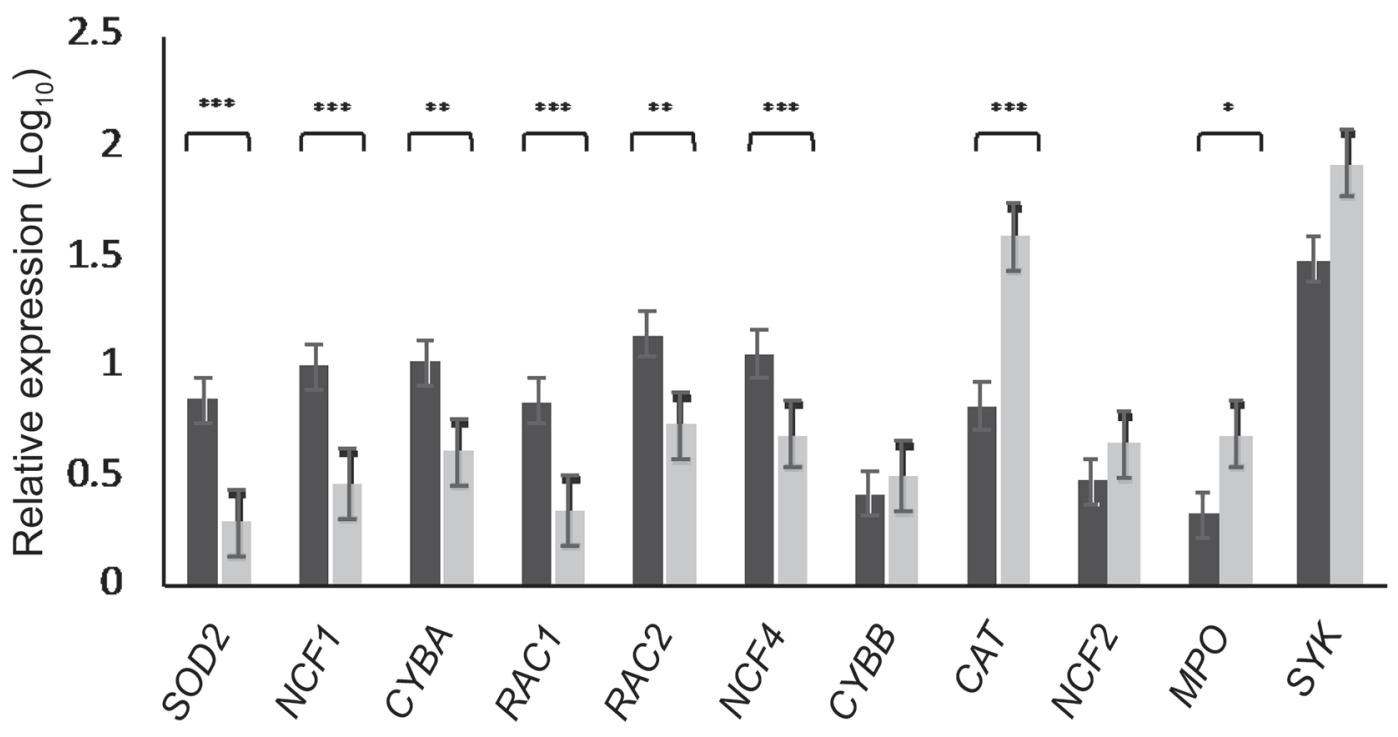

Figure 4. Quantitative real-time PCR analysis showing the effect of lactation stage on the expression of several genes involved in the neutrophil reactive oxygen species pathway. Bars represents mean expression (logarithmic scale) \pm SEM normalized by the expression of 4 reference genes as described by Vandesompele et al. (2002). Dark gray bars represent neutrophils obtained from periparturient cows $(\mathrm{d}=0)$, and light gray bars represent neutrophils obtained from mid-lactation cows $(\mathrm{d}=135 \pm 7)$. Significant differences between periparturient and mid-lactation cows are denoted with asterisks $\left({ }^{*} P<0.05\right.$; ${ }^{* *} P<0.01$; $\left.{ }^{* * *} P<0.001\right)$. 
Table 3. Correlation of gene expression and reactive oxygen species production

\begin{tabular}{|c|c|c|c|c|}
\hline Item & $\begin{array}{l}\text { Difference in gene } \\
\text { expression } P \text {-value }\end{array}$ & $\begin{array}{c}\text { Mean relative } \\
\text { expression }(\mathrm{P} / \mathrm{M})^{2}\end{array}$ & $\begin{array}{l}\text { Correlation } \\
\text { coefficient }^{3}\end{array}$ & $\begin{array}{c}\text { Correlation } \\
\text { coefficient } \\
P \text {-value }\end{array}$ \\
\hline \multicolumn{5}{|c|}{ Increased expression during periparturition } \\
\hline$R A C 1$ & $0.00004^{* * *}$ & 2.59 & 0.13 & $0.00001^{* * *}$ \\
\hline NCF1 & $0.00015^{* * *}$ & 2.48 & 0.05 & $0.00001^{* * *}$ \\
\hline$C Y B A$ & $0.00136^{* *}$ & 1.65 & 0.18 & $0.002^{* *}$ \\
\hline \multicolumn{5}{|c|}{ Decreased expression during periparturition } \\
\hline$C Y B B$ & 0.30984 & -1.22 & 0.11 & 0.19822 \\
\hline$S Y K$ & 0.24973 & -1.27 & 0.11 & 0.10454 \\
\hline NCF2 & 0.17927 & -1.35 & 0.04 & 0.10545 \\
\hline CAT & $0.00015^{* * *}$ & -1.89 & -0.05 & $0.00004^{* * *}$ \\
\hline$M P O$ & $0.03403^{*}$ & -2.12 & 0.08 & $0.00554^{*}$ \\
\hline
\end{tabular}

${ }^{1} P$-values of differences in gene expression between periparturient and mid-lactation cows.

${ }^{2}$ Mean relative expression of periparturient (P) cows compared with mid-lactation (M) cows (denoted as fold increase or decrease).

${ }^{3}$ Correlation coefficient of reactive oxygen species production (time to reach the maximum) and gene expression profile.

${ }^{4} P$-value of correlation coefficient.

${ }^{*} P<0.05 ;{ }^{* *} P<0.005 ;{ }^{* * *} P<0.001$.

(slope) but prolonged $\left(\mathrm{T}_{1 / 2}\right)$ production of ROS compared with the mid-lactating group. Considering the similar AUC, these results thus indicate that periparturient cows need more time to produce the same amount of ROS during the first $90 \mathrm{~min}$.

Although we did not evaluate MPO activity on protein level, the well-known decrease in MPO activity in periparturient cows (Kehrli et al., 1989; Cai et al., 1994; Hammon et al., 2006) was underpinned in our study by a significant decrease in $M P O$ gene expression during this period (Figure 4). Curiously, several genes coding for the subsets of NADPH oxidase $(C Y B A)$ and its regulatory proteins (NCF1,NCF4, RAC1, RAC2) were upregulated during the same period, which suggests that the MPO-independent oxidative burst is increased in periparturient cows.

We found striking similarities in ROS production between humans with MPO deficiency and our periparturient cows with a transient decrease of $M P O$ expression. Compared with volunteers with normal MPO levels, MPO-deficient patients show a decreased CL during the early postphagocytic period after phagocytosis of zymosan, which can be seen as a delayed production of ROS (Rosen and Klebanoff, 1976; Klebanoff et al., 2013). This was reflected in a decreased slope in our periparturient cows after stimulation with OZ (Figure 3A). At 10 min after the addition of zymosan, CL by MPO-deficient leukocytes is significantly lower than CL

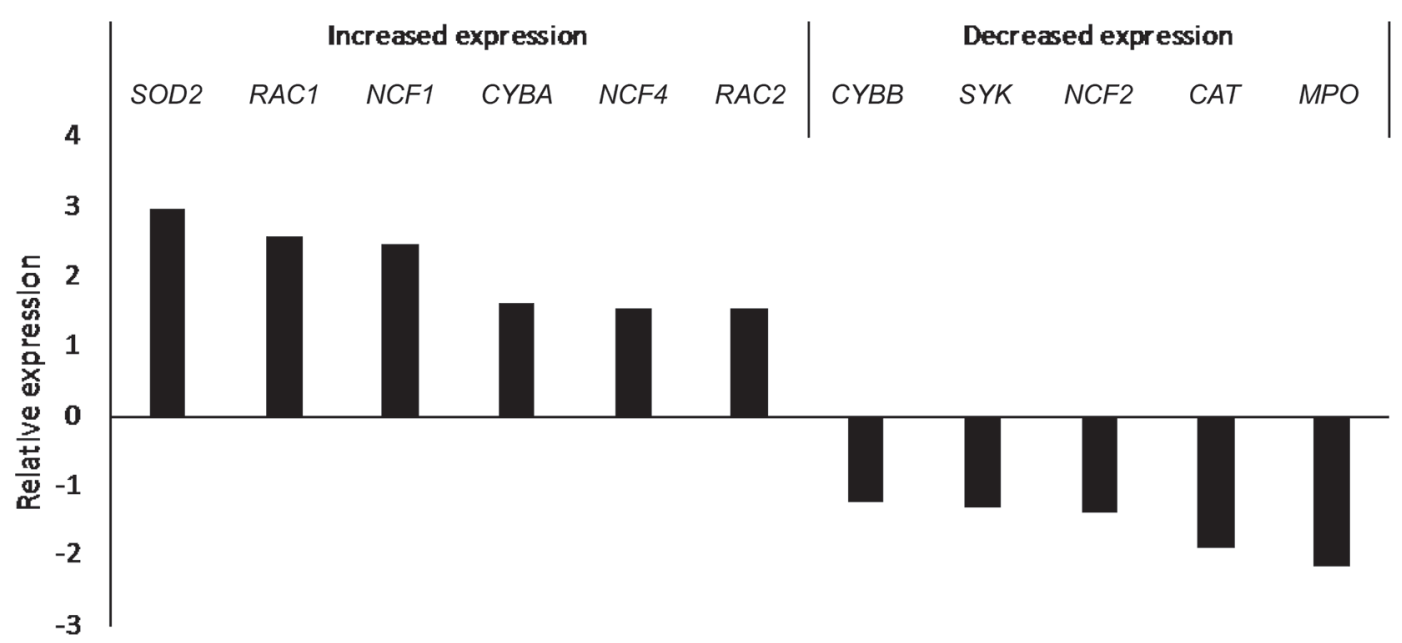

Figure 5. Mean fold gene expression of target genes. Analysis of the mean expression of the different target genes revealed the differences in expression between the 2 lactation stages. The highest increase in expression in primiparous cows was observed for SOD2, whereas the highest decrease was found for $M P O$. 


\begin{tabular}{|c|c|c|c|c|c|c|c|c|c|c|c|c|c|c|c|c|c|c|c|c|c|c|c|c|c|c|c|c|c|c|c|c|c|}
\hline \multicolumn{8}{|c|}{$M P O$} & \multicolumn{26}{|c|}{ SOD2 } \\
\hline \multicolumn{4}{|c|}{ PRIMER 1} & \multicolumn{4}{|c|}{ PRIMER 2} & \multicolumn{3}{|c|}{ PRIMER 1} & \multicolumn{4}{|c|}{ PRIMER 2} & & $\begin{array}{l}\text { PRIM } \\
\text { (conti }\end{array}$ & $\begin{array}{l}\text { ER } 2 \\
\text { aue d) }\end{array}$ & & PRIM & IER 3 & & & $\begin{array}{l}\text { PRIM } \\
\text { (conti }\end{array}$ & $\begin{array}{l}\text { MER } \\
\text { inued }\end{array}$ & & & PRIN & MER 4 & & & PRIM & $\mathbb{Z} R \mathrm{R}$ & \\
\hline 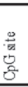 & 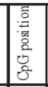 & 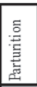 & 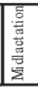 & 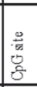 & 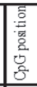 & 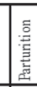 & 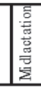 & 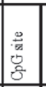 & 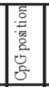 & 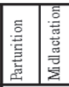 & 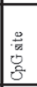 & 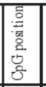 & 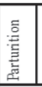 & 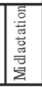 & \begin{tabular}{|l} 
量 \\
0 \\
0 \\
5
\end{tabular} & 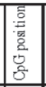 & 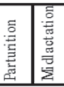 & $\begin{array}{l}\frac{2}{5} \\
0 \\
0 \\
0 \\
\end{array}$ & 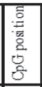 & 言 & 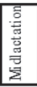 & 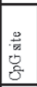 & 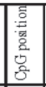 & \begin{tabular}{|l} 
言 \\
意 \\
\end{tabular} & 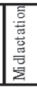 & $\begin{array}{l}\frac{8}{5} \\
\text { E. } \\
\stackrel{5}{5}\end{array}$ & 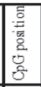 & \begin{tabular}{|l|} 
总 \\
意 \\
意 \\
\end{tabular} & 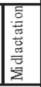 & 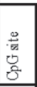 & 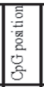 & 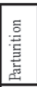 & 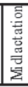 \\
\hline 1 & 1 & 30 & 10 & 1 & 14 & 0 & 0 & 1 & 43 & 84 & 1 & 2 & 0 & 0 & 51 & 424 & $0 \quad 0$ & 1 & 9 & 0 & 0 & 51 & 334 & 0 & 0 & 1 & 1 & 0 & 0 & 1 & 24 & 0 & 0 \\
\hline 2 & 8 & 22 & 18 & 2 & 21 & 0 & 0 & 2 & 52 & 0 & 2 & 13 & 10 & 10 & 52 & 428 & 0 & 2 & 17 & 0 & 0 & 52 & 336 & 0 & 0 & 2 & 7 & 0 & 0 & 2 & 29 & 0 & 0 \\
\hline 3 & 19 & 35 & 10 & 3 & 37 & 0 & 0 & 3 & 61 & 0 & 3 & 31 & 0 & 0 & 53 & 434 & 0 & 3 & 23 & 0 & 4 & 53 & 342 & 0 & 0 & 3 & 9 & 0 & 0 & 3 & 51 & 0 & 0 \\
\hline 4 & 40 & 30 & 14 & 4 & 45 & 0 & 4 & 4 & 73 & 0 & 4 & 41 & 0 & 8 & 54 & 446 & 4 & 4 & 26 & 0 & 17 & 54 & 352 & 0 & 0 & 4 & 13 & 0 & 4 & 4 & 65 & 13 & 0 \\
\hline 5 & 44 & 31 & 28 & 5 & 63 & 0 & 0 & 5 & 134 & 0 & 5 & 47 & 0 & 0 & & & & 5 & 37 & 0 & 0 & 55 & 356 & 0 & 0 & 5 & 15 & 0 & 4 & 5 & 67 & 0 & 0 \\
\hline 6 & 54 & 40 & 14 & 6 & 82 & 0 & 0 & 6 & 148 & 0 & 6 & 49 & 0 & 0 & & & & 6 & 39 & 0 & 0 & 56 & 359 & 0 & 0 & 6 & 32 & 0 & 0 & 6 & 73 & 0 & 0 \\
\hline 7 & 61 & 20 & 25 & 7 & 94 & 0 & 0 & 7 & 153 & 0 & 7 & 52 & 0 & 0 & & & & 7 & 43 & 0 & 0 & 57 & 361 & 0 & 0 & 7 & 36 & 0 & 0 & 7 & 75 & 4 & 0 \\
\hline 8 & 68 & 50 & 21 & 8 & 117 & 0 & 0 & 8 & 185 & 0 & 8 & 59 & 0 & 0 & & & & 8 & 59 & 0 & 4 & 58 & 367 & 0 & 5 & 8 & 47 & 0 & 0 & 8 & 79 & 0 & 0 \\
\hline 9 & 72 & 39 & 18 & 9 & 129 & 0 & 0 & 9 & 200 & 0 & 9 & 65 & 0 & 0 & & & & 9 & 66 & 0 & 0 & 59 & 377 & 0 & 0 & 9 & 49 & 0 & 0 & 9 & 90 & 0 & 4 \\
\hline 10 & 114 & 8 & 14 & 10 & 144 & 0 & 0 & \begin{tabular}{l|l}
10 \\
\end{tabular} & 209 & 0 & 10 & 70 & 0 & 0 & & & & 10 & 81 & 0 & 0 & 60 & 381 & 0 & 0 & 10 & 74 & 0 & 0 & 10 & 92 & 4 & 0 \\
\hline 11 & 133 & 50 & 27 & 11 & 146 & 0 & 0 & \begin{tabular}{|l|}
11 \\
\end{tabular} & 218 & 0 & 11 & 75 & 0 & 0 & & & & 11 & 83 & 4 & 0 & 61 & 386 & 8 & 0 & 11 & 92 & 0 & 4 & 11 & 95 & 4 & 0 \\
\hline 12 & 160 & 33 & 21 & 12 & 150 & 0 & 4 & 12 & 227 & 0 & 12 & 107 & 0 & 0 & & & & 12 & 92 & 0 & 0 & 62 & 392 & 0 & 0 & 12 & 102 & 0 & 0 & 12 & \begin{tabular}{|l|}
98 \\
\end{tabular} & 0 & 0 \\
\hline 13 & 172 & 38 & 21 & 13 & 154 & 0 & 4 & 13 & 249 & 0 & 13 & 116 & 0 & 0 & & & & 13 & 94 & 0 & 0 & 63 & \begin{tabular}{|l|l|} 
\\
\end{tabular} & 0 & 0 & 13 & 115 & 0 & 0 & 13 & 124 & 0 & 0 \\
\hline 14 & 182 & 22 & 18 & 14 & 159 & 0 & 0 & 14 & 260 & 0 & 14 & 124 & 0 & 0 & & & & 14 & 98 & 0 & 5 & 64 & 404 & 0 & 0 & 14 & 135 & 0 & 0 & 14 & 129 & 0 & 0 \\
\hline 15 & 185 & 43 & 17 & 15 & 171 & 0 & 0 & 15 & 278 & 0 & 15 & 147 & 0 & 0 & & & & 15 & 119 & 4 & 5 & 65 & 406 & 0 & 0 & 15 & 143 & 0 & 0 & 15 & 134 & 4 & 0 \\
\hline 16 & 192 & 16 & 13 & 16 & 177 & 0 & 0 & 16 & 288 & 0 & 16 & 153 & 0 & 0 & & & & 16 & 130 & 0 & 0 & 66 & 409 & 0 & 0 & 16 & \begin{tabular}{|l|}
147 \\
\end{tabular} & 0 & 0 & 16 & 139 & 0 & 0 \\
\hline 17 & 206 & 27 & 18 & 17 & 183 & 0 & 0 & 17 & 294 & 0 & 17 & \begin{tabular}{|l|}
157 \\
\end{tabular} & 0 & 0 & & & & 17 & 139 & 0 & 0 & & & & & 17 & 153 & 0 & 0 & 17 & \begin{tabular}{|l|}
144 \\
\end{tabular} & 4 & 0 \\
\hline 18 & 216 & 20 & 7 & 18 & 218 & 0 & 0 & 18 & 296 & 0 & 18 & 173 & 0 & 0 & & & & 18 & 142 & 4 & 0 & & & & & 18 & 156 & 0 & 0 & 18 & 151 & 0 & 0 \\
\hline 19 & 224 & 4 & 7 & 19 & 229 & 0 & 0 & 19 & 299 & 0 & 19 & 179 & 0 & 0 & & & & 19 & 148 & 4 & 0 & & & & & 19 & 167 & 0 & 0 & 19 & 165 & 0 & 0 \\
\hline 20 & 229 & 7 & 7 & 20 & 244 & 0 & 0 & 20 & 306 & 0 & 20 & 181 & 0 & 0 & & & & 20 & 150 & 0 & 0 & & & & & 20 & 177 & 0 & 0 & 20 & 169 & 0 & 0 \\
\hline 21 & 238 & 7 & 21 & 21 & 254 & 0 & 0 & 21 & 312 & 0 & 21 & 190 & 0 & 0 & & & & 21 & 154 & 0 & 0 & & & & & 21 & 179 & 0 & 0 & 21 & 173 & 0 & 0 \\
\hline 22 & 243 & 0 & 0 & 22 & 258 & 0 & 0 & 22 & 317 & 0 & 22 & 195 & 0 & 0 & & & & 22 & 158 & 0 & 0 & & & & & & & & & 22 & 193 & 0 & 4 \\
\hline 23 & 274 & 0 & 0 & 23 & 273 & 0 & 0 & & & & 23 & 200 & 0 & 0 & & & & 23 & 161 & 0 & 0 & & & & & & & & & 23 & 200 & 0 & 0 \\
\hline 24 & 294 & 0 & 0 & 24 & 276 & 0 & 0 & & & & 24 & 202 & 0 & 0 & & & & 24 & 163 & 4 & 0 & & & & & & & & & 24 & 213 & 0 & 0 \\
\hline 25 & 298 & 0 & 0 & 25 & 278 & 0 & 0 & & & & 25 & 222 & 0 & 4 & & & & 25 & 167 & 0 & 0 & & & & & & & & & 25 & \begin{tabular}{|l|}
216 \\
\end{tabular} & 0 & 0 \\
\hline 26 & 306 & 0 & 0 & 26 & 294 & 0 & 0 & & & & 26 & 224 & 0 & 0 & & & & 26 & 174 & 0 & 0 & & & & & & & & & 26 & 219 & 0 & 0 \\
\hline 27 & 316 & 0 & 3 & 27 & 298 & 0 & 0 & & & & 27 & 229 & 4 & 0 & & & & 27 & 190 & 0 & 0 & & & & & & & & & 27 & 234 & 0 & 0 \\
\hline 28 & 320 & 0 & 3 & 28 & 308 & 0 & 4 & & & & 28 & 231 & 0 & 0 & & & & 28 & 193 & 0 & 0 & & & & & & & & & 28 & 241 & 4 & 0 \\
\hline 29 & 336 & 0 & 0 & 29 & 316 & 0 & 0 & & & & 29 & 238 & 0 & 4 & & & & 29 & 197 & 8 & 0 & & & & & & & & & 29 & 243 & 0 & 0 \\
\hline 30 & 338 & 0 & 0 & 30 & 320 & 0 & 0 & & & & 30 & 249 & 0 & 17 & & & & 30 & 199 & 25 & 18 & & & & & & & & & 30 & 277 & 4 & 0 \\
\hline 31 & 341 & 3 & 0 & 31 & 340 & 0 & 4 & & & & 31 & 255 & 0 & 0 & & & & 31 & 214 & 0 & 0 & & & & & & & & & 31 & \begin{tabular}{|l|}
279 \\
\end{tabular} & 0 & 0 \\
\hline 32 & 356 & 0 & 7 & & & & & & & & 32 & 260 & 0 & 0 & & & & 32 & 217 & 5 & 0 & & & & & & & & & 32 & 289 & 0 & 0 \\
\hline 33 & 360 & 0 & 0 & & & & & & & & 33 & 268 & 4 & 0 & & & & 33 & 221 & 4 & 0 & & & & & & & & & 33 & 300 & 0 & 0 \\
\hline 34 & 370 & 0 & 0 & & & & & & & & 34 & 282 & 18 & 14 & & & & 34 & 232 & 0 & 0 & & & & & & & & & 34 & \begin{tabular}{|l|}
303 \\
\end{tabular} & 0 & 0 \\
\hline 35 & 385 & 0 & 0 & & & & & & & & 35 & 307 & 0 & 0 & & & & 35 & 239 & 0 & 0 & & & & & & & & & 35 & 309 & 0 & 0 \\
\hline 36 & 396 & 4 & 0 & & & & & & & & 36 & 322 & 0 & 0 & & & & 36 & 249 & 5 & 0 & & & & & & & & & 36 & 313 & 0 & 4 \\
\hline & & & & & & & & & & & 37 & 325 & 0 & 0 & & & & 37 & 252 & 0 & 0 & & & & & & & & & 37 & 321 & 0 & 0 \\
\hline & & & & & & & & & & & 38 & 327 & 0 & 0 & & & & 38 & 254 & 0 & 0 & & & & & & & & & 38 & 341 & 0 & 0 \\
\hline & & & & & & & & & & & 39 & 331 & 0 & 0 & & & & 39 & 267 & 0 & 4 & & & & & & & & & 39 & 354 & 0 & 0 \\
\hline & & & & & & & & & & & 40 & \begin{tabular}{|l|}
337 \\
\end{tabular} & 0 & 0 & & & & 40 & 272 & 4 & 0 & & & & & & & & & 40 & 364 & 4 & 0 \\
\hline & & & & & & & & & & & 41 & \begin{tabular}{|l|}
339 \\
\end{tabular} & 0 & 0 & & & & 41 & 283 & 0 & 0 & & & & & & & & & & & & \\
\hline & & & & & & & & & & & 42 & 345 & 0 & 4 & & & & 42 & 290 & 0 & 0 & & & & & & & & & & & & \\
\hline & & & & & & & & & & & 43 & 359 & 0 & 0 & & & & 43 & 293 & 0 & 0 & & & & & & & & & & & & \\
\hline & & & & & & & & & & & 44 & 361 & 0 & 4 & & & & 44 & 307 & 0 & 0 & & & & & & & & & & & & \\
\hline & & & & & & & & & & & 45 & 366 & 0 & 0 & & & & 45 & 310 & 0 & 0 & & & & & & & & & & & & \\
\hline & & & & & & & & & & & 46 & \begin{tabular}{|l|}
368 \\
\end{tabular} & 0 & 0 & & & & 46 & 312 & 0 & 0 & & & & & & & & & & & & \\
\hline & & & & & & & & & & & 47 & 374 & 0 & 0 & & & & 47 & 318 & 0 & 0 & & & & & & & & & & & & \\
\hline & & & & & & & & & & & 48 & \begin{tabular}{|l|}
377 \\
\end{tabular} & 0 & 0 & & & & 48 & 325 & 0 & 0 & & & & & & & & & & & & \\
\hline & & & & & & & & & & & 49 & 389 & 0 & 0 & & & & 49 & 327 & 0 & 0 & & & & & & & & & & & & \\
\hline & & & & & & & & & & & 50 & 408 & 0 & 0 & & & & 50 & 329 & 0 & 0 & & & & & & & & & & & & \\
\hline
\end{tabular}

Figure 6. Methylation state of $\mathrm{CpG}$ islands of $M P O$ and SOD2. Percentage of methylation is given per CpG site and is represented by a color gradient. White squares correspond to $\mathrm{CpG}$ islands where we found $0 \%$ methylated C. Gray squares represent methylated $\mathrm{C}$.

of normal cells, resulting in a lower AUC and a delayed MAX. This delay in MAX was also seen in our periparturient cows (Figure 3A). In addition, with continued incubation, CL of normal human leukocytes decreased to a level below that of the deficient group. This latter observation was also seen in our study, as shown by the crossing over the graphs of both lactation stages, where periparturient neutrophils show a prolonged production of ROS (Figure 3A). These insights might explain why Rinaldi et al. (2008) observed an increased AUC after luminol-induced CL in periparturient cows, as their results are based on a longer incubation period compared with the present study and other studies mentioned above. At 90 min of incubation, our peri- 
parturient neutrophils still produced more ROS than the mid-lactation neutrophils. A longer incubation time would have confirmed the higher AUC found by Rinaldi et al. (2008).

Neutrophils deficient in MPO, as shown in humans, kill susceptible bacteria more slowly but mostly achieve the same success in the end, by which death of the organism is observed (Nauseef, 2014). In in vivo situations, however, fast recruitment of neutrophils is indispensable for a balanced inflammatory reaction. For example, in cows, a fast recruitment of neutrophils is necessary to protect the mammary gland efficiently against invading pathogens (Paape et al., 2003), whereas delayed recruitment is correlated with severity in E. coli mastitis (Kremer et al., 1993; Vandeputte-Van Messom et al., 1993). A delay in ROS production might contribute to the increased severity of disease observed in periparturient cows (Burvenich et al., 2003). In addition, MPO-deficient neutrophils exhibit an increased phagocytosis, which appears to be dependent on MPO (Klebanoff, 1991). This is remarkable because bovine neutrophils are known to show an increased phagocytosis around parturition (Kehrli et al., 1989). It makes $\mathrm{MPO}$ an interesting player in the prevention of periparturient diseases, as the first week postpartum has been correlated with a decreased iodination capacity of MPO in many previous studies (e.g., Kehrli et al., 1989; Cai et al., 1994; Hammon et al., 2006).

Taken together, our results indicate that during the periparturient period, cows (1) show delayed ROS production at the phenotypic level, (2) confirm a decrease in MPO activity at the transcriptional level, and (3) show an increase in the transcription of genes involved in the NADPH oxidase-dependent burst. An increased NADPH-dependent oxidative burst during peripartum would imply that neutrophils consume more oxygen and produce more $\mathrm{O}_{2}{ }^{-}$and $\mathrm{H}_{2} \mathrm{O}_{2}$ during this period. Remarkably, SOD2, responsible for the first detoxification of $\mathrm{O}_{2}{ }^{-}$to $\mathrm{H}_{2} \mathrm{O}_{2}$, was also upregulated in the periparturient cows, whereas catalase, responsible for further breakdown of $\mathrm{H}_{2} \mathrm{O}_{2}$ to $\mathrm{H}_{2} \mathrm{O}$, is less expressed; this suggests an increase in $\mathrm{H}_{2} \mathrm{O}_{2}$ concentration in neutrophils. Rinaldi et al. (2008) compared the production of different ROS between the 2 lactation stages and found a significant increase of $\mathrm{H}_{2} \mathrm{O}_{2}$ production in periparturient cows compared with mid-lactation cows. Studies in murine and human MPO-deficient individuals suggested that the MPO-deficient cells adapt to the long-term absence of MPO with an increase in the activity of the MPO-independent antimicrobial systems (Figure 4).

In this longitudinal study, the differential gene expression profiles between the periparturient period and mid lactation emphasize the importance of understand- ing how gene expression is controlled in neutrophils. Curiously, little attention has been devoted to comprehensive investigation of the influence of epigenomic DNA modifications in bovine neutrophils until now. Epigenetic modifications are not only crucial for the regulation of developmental processes of cells or organisms, they are also involved in coping with endogenous and environmental signals during a cell or organism's life. Hence, differential gene expression is variable not only in space but also in time (reviewed by Jaenisch and Bird, 2003). It has been reported that sepsis can result in epigenetic changes in hematopoietic progenitor cells and in turn diminish the function of the differentiated progeny (Carson et al., 2011). Physiological adaptations around parturition set up an altered environment for neutrophils. It is not unlikely that this altered internal environment plays a crucial role in the periparturient neutrophil phenotype. During this period, marked changes are observed in various systemic and local hormones. Estrogen and progesterone, for example, can also act as survival factors in different tissues. In some studies an effect on the oxidative burst in neutrophils has also been reported (reviewed by Vangroenweghe et al., 2005). Based on our previous study (Stevens et al., 2011), we hypothesized that cows may adapt to their metabolic and endocrine demands through epigenetic regulation mechanisms.

The SOD2 and $M P O$ genes, 2 genes with a markedly different expression between the 2 lactation stages in our study and both key players in the neutrophil oxidative burst, were checked for the methylation pattern of carefully selected $\mathrm{CpG}$ islands. It was reported before that whole-DNA methylation in pregnant women before and during pregnancy shows time-dependent changes in methylation (Pauwels et al., 2017). We assumed that, if the oxidative burst is subjected to lactation stagedependent changes in methylation, this effect would be most distinct in the genes with the biggest difference in expression. The negative correlation between gene expression and methylation is well established (Jaenisch and Bird, 2003), and eventual differences might offer an explanation for the periparturient gene expression profile. Although we found differences in methylation between the 2 lactation stages, they were not significant. Based on our results, it was not possible to conclude whether lactation stage has an effect on the methylation patterns of the investigated $\mathrm{CpG}$ islands. Possibly, our study group was too small to formulate a conclusion about the effect of methylation in the selected regions. On the other hand, the molecular basis of epigenesis is complex, and other reasons can account for the lack of differences in our study. For example, a different mechanism may regulate the expression of our selected genes. Next to DNA methylation, several 
DNA modifications can maintain a particular epigenetic state, including posttranslational modifications of histones, noncoding RNA, and nucleosome positioning along the DNA and genome instabilities (Jin et al., 2011; González-Recio et al., 2015). In addition, locations other than those investigated in this study might be subjected to alterations in methylation.

\section{CONCLUSIONS}

Parturition induces a shift in focus of the oxidative burst toward a delayed and a more MPO-independent killing strategy. This might lead to a delay in killing, especially when susceptible bacteria are involved. We could not identify an increase in DNA methylation level in the targeted $\mathrm{CpG}$ islands, and thus other mechanisms must influence the expression levels of the ROS-related genes investigated in this study.

\section{REFERENCES}

Adrover, J. M., J. A. Nicolás-Ávila, and A. Hidalgo. 2016. Aging: A temporal dimension for neutrophils. Trends Immunol. 37:334-345. https://doi.org/10.1016/j.it.2016.03.005.

Burton, J. L., S. A. Madsen, L. C. Chang, P. S. D. Weber, K. R. Buckham, R. V. Dorp, M. C. Hickey, and B. Earley. 2005. Gene expression signatures in neutrophils exposed to glucocorticoids: A new paradigm to help explain "neutrophil dysfunction" in parturient dairy cows. Vet. Immunol. Immunopathol. 105:197-219.

Burvenich, C., D. D. Bannerman, J. D. Lippolis, L. Peelman, B. J. Nonnecke, M. E. Kehrli Jr., and M. J. Paape. 2007. Cumulative physiological events influence the inflammatory response of the bovine udder to Escherichia coli infections during the transition period. J. Dairy Sci. 90(Suppl. 1):E39-E54.

Burvenich, C., M. J. Paape, A. W. Hill, A. J. Guidry, R. H. Miller, R. Heyneman, W. D. Kremer, and A. Brand. 1994. Role of the neutrophil leucocyte in the local and systemic reactions during experimentally induced $E$. coli mastitis in cows immediately after calving. Vet. Q. 16:45-50.

Burvenich, C., V. Van Merris, J. Mehrzad, A. Diez-Fraile, and L. Duchateau. 2003. Severity of E. coli mastitis is mainly determined by cow factors. Vet. Res. 34:521-564. https://doi.org/10.1051/vetres: 2003023.

Bustin, S. A., V. Benes, J. A. Garson, J. Hellemans, J. Huggett, M. Kubista, R. Mueller, T. Nolan, M. W. Pfaffl, G. L. Shipley, J. Vandesompele, and C. T. Wittwer. 2009. The MIQE guidelines: Minimum information for publication of quantitative real-time PCR experiments. Clin. Chem. 55:611-622. https://doi.org/10 .1373 /clinchem.2008.112797.

Cai, T. Q., P. G. Weston, L. A. Lund, B. Brodie, D. J. McKenna, and W. C. Wagner. 1994. Associations between neutrophil functions and periparturient disorders in cows. Am. J. Vet. Res. 55:934-943.

Carson, W. F., K. A. Cavassani, Y. Dou, and S. L. Kunkel. 2011. Epigenetic regulation of immune cell functions during post-septic immunosuppression. Epigenetics 6:273-283. https://doi.org/0.4161/ epi.6.3.14017.

Crookenden, M. A., A. Heiser, A. Murray, V. S. R. Dukkipati, J. K. Kay, J. J. Loor, S. Meier, M. D. Mitchell, K. M. Moyes, C. G. Walker, and J. R. Roche. 2016. Parturition in dairy cows temporarily alters the expression of genes in circulating neutrophils. J. Dairy Sci. 99:6470-6483. https://doi.org/10.3168/jds.2015-10877.

Decoursey, T. E., and E. Ligeti. 2005. Regulation and termination of NADPH oxidase activity. Cell. Mol. Life Sci. 62:2173-2193. https: //doi.org/10.1007/s00018-005-5177-1.
DeLeo, F. R., L. A. H. Allen, M. Apicella, and W. M. Nauseef. 1999. NADPH oxidase activation and assembly during phagocytosis. J. Immunol. 163:6732-6740.

Dupré-Crochet, S., M. Erard, and O. Nüße. 2013. ROS production in phagocytes: Why, when, and where? J. Leukoc. Biol. 94:657-670. https://doi.org/10.1189/jlb.1012544.

El-Benna, J., P. M. Dang, M. A. Gougerot-Pocidalo, J. C. Marie, and F. Braut-Boucher. 2009. p47phox, the phagocyte NADPH oxidase/NOX2 organizer: Structure, phosphorylation and implication in diseases. Exp. Mol. Med. 41:217-225. https://doi.org/10.3858/ emm.2009.41.4.058.

González-Recio, O., M. A. Toro, and A. Bach. 2015. Past, present, and future of epigenetics applied to livestock breeding. Front. Genet. https://doi.org/10.3389/fgene.2015.00305.

Goossens, K., M. Van Poucke, A. Van Soom, J. Vandesompele, A. Van Zeveren, and L. Peelman. 2005. Selection of reference genes for quantitative real-time PCR in bovine preimplantation embryos. BMC Dev. Biol. 5:27. https://doi.org/10.1186/1471-213X-5-27.

Hall, T. A. 1999. BioEdit: A user-friendly biological sequence alignment editor and analysis program for Windows 95/98/NT. Nucl. Acids Symp. 41:95-98.

Hammon, D. S., I. M. Evjen, T. R. Dhiman, J. P. Goff, and J. L. Walters. 2006. Neutrophil function and energy status in Holstein cows with uterine health disorders. Vet. Immunol. Immunopathol. 113:21-29. https://doi.org/10.1016/j.vetimm.2006.03.022.

Hellebrekers, P., N. Vrisekoop, and L. Koenderman. 2018. Neutrophil phenotypes in health and disease. Eur. J. Clin. Invest. 48:e12943 https://doe.org/10.1111/eci.12943.

Hellemans, J., and J. Vandesompele. 2011. qPCR data analysis-Unlocking the secret to successful results. In PCR Troubleshooting and Optimization: The Essential Guide. S. Kennedy and N. Oswald, ed. Caister Academic Press, Poole, UK.

Heyneman, R., C. Burvenich, and R. Vercauteren. 1990. Interaction between the respiratory burst activity of neutrophil leukocytes and experimentally induced Escherichia coli mastitis in cows. J. Dairy Sci. 73:985-994.

Hill, A. W. 1981. Factors influencing the outcome of Escherichia coli mastitis in the dairy cow. Res. Vet. Sci. 31:107-112.

Hill, A. W., A. L. Shears, and K. G. Hibbitt. 1979. The pathogenesis of experimental Escherichia coli mastitis in newly calved dairy cows. Res. Vet. Sci. 26:97-101.

Hoeben, D., E. Monfardini, G. Opsomer, H. Dosogne, A. De Kruif, J. F. Beckers, and C. Burvenich. 2000. Chemiluminescence of bovine polymorphonuclear leukocytes during the periparturient period and relation with metabolic parameters and bovine pregnancyassociated glycoprotein. J. Dairy Res. 67:249-259.

Hurst, J. K. 2012. What really happens in the neutrophil phagosome? Free Radic. Biol. Med. 53:508-520. https://doi.org/10.1016/j freeradbiomed.2012.05.008.

Jaenisch, R., and A. Bird. 2003. Epigenetic regulation of gene expression: How the genome integrates intrinsic and environmental signals. Nat. Genet. 33(Suppl.):245-254. https://doi.org/10.1038/ ng1089.

Jin, B., Y. Li, and K. D. Robertson. 2011. DNA methylation: Superior or subordinate in the epigenetic hierarchy? Genes Cancer 2:607617. https://doi.org/10.1177/1947601910393957.

Kehrli, M. E., B. J. Nonnecke, and J. A. Roth. 1989. Alterations in bovine peripheral blood neutrophil function during the periparturient period. Am. J. Vet. Res. 50:207-214.

Kent, W. J., C. W. Sugnet, T. S. Furey, K. M. Roskin, T. H. Pringle, A. M. Zahler, and D. Haussler. 2002. The human genome browser at UCSC. Genome Res. 12:996-1006.

Klebanoff, S. J. 1991. Chapter 1: Myeloperoxidase: Occurrence and biological function. Pages 1-36 in Peroxidases in Chemistry and Biology. Vol. I. J. Everse, K. E. Everse, and M. B. Grisham, ed. CRC Press, Boca Raton, FL

Klebanoff, S. J., A. J. Kettle, H. Rosen, C. C. Winterbourn, and W. M. Nauseef. 2013. Myeloperoxidase: A front-line defender against phagocytosed microorganisms. J. Leukoc. Biol. 93:185-198. https: //doi.org/10.1189/jlb.0712349. 
Klink, M., K. Bednarska, E. Blus, M. Kielbik, and Z. Sulowska. 2012. Seasonal changes in activities of human neutrophils in vitro. Inflamm. Res. 61:11-16. https://doi.org/10.1007/s00011-011-0382-x.

Kolaczkowska, E., and P. Kubes. 2013. Neutrophil recruitment and function in health and inflammation. Nat. Rev. Immunol. 13:159175. https://doi.org/10.1038/nri3399.

Kremer, W. D. J., E. N. Noordhuizen-Stassen, F. J. Grommers, A. J. J. M. Daemen, and A. Brand. 1993. Blood polymorphonuclear leukocyte chemotaxis during experimental Escherichia coli bovine mastitis. J. Dairy Sci. 76:2613-2618.

Kuo, H. C., P. Y. Lin, T. C. Chung, C. M. Chao, L. C. Lai, M.-H. Tsai, and E. Y. Chuang. 2011. DBCAT: Database of CpG islands and analytical tools for identifying comprehensive methylation profiles in cancer cells. J. Comput. Biol. 18:1013-1017. https://doi.org/10 $.1089 / \mathrm{cmb} .2010 .0038$.

Li, Y., and T. O. Tollefsbol. 2011. DNA methylation detection: Bisulfite genomic sequencing analysis. Methods Mol. Biol. 791:11-21.

Lieberman, M. M., D. M. Sachanandani, and C. A. Pinney. 1996 Comparative study of neutrophil activation by chemiluminescence and flow cytometry. Clin. Diagn. Lab. Immunol. 3:654-662.

Lippolis, J. D., B. D. Peterson-Burch, and T. A. Reinhardt. 2006. Differential expression analysis of proteins from neutrophils in the periparturient period and neutrophils from dexamethasone-treated dairy cows. Vet. Immunol. Immunopathol. 111:149-164.

Madsen, S. A., L. C. Chang, M. C. Hickey, G. J. Rosa, P. M. Coussens, and J. L. Burton. 2004. Microarray analysis of gene expression in blood neutrophils of parturient cows. Physiol. Genomics 16:212-221. https://doi.org/10.1152/physiolgenomics.00121.2003.

Mehrzad, J., H. Dosogne, E. Meyer, and C. Burvenich. 2001. Local and systemic effects of endotoxin mastitis on the chemiluminescence of milk and blood neutrophils in dairy cows. Vet. Res. 32:131-144.

Mehrzad, J., L. Duchateau, S. Pyörälä, and C. Burvenich. 2002. Blood and milk neutrophil chemiluminescence and viability in primiparous and pluriparous dairy cows during late pregnancy, around parturition and early lactation. J. Dairy Sci. 85:3268-3276.

National Mastitis Council. 1999. Laboratory Handbook on Bovine Mastitis. National Mastitis Council, Madison, WI.

Nauseef, W. M. 2014. Myeloperoxidase in human neutrophil host defence. Cell. Microbiol. 16:1146-1155. https://doi.org/10.1111/cmi .12312 .

Paape, M. J., D. D. Bannerman, X. Zhao, and J. W. Lee. 2003. The bovine neutrophil: Structure and function in blood and milk. Vet. Res. 34:597-627. https://doi.org/10.1051/vetres:2003024.

Pauwels, S., M. Ghosh, R. C. Duca, B. Bekaert, K. Freson, I. Huybrechts, S. A. S. Langie, G. Koppen, R. Devlieger, and L. Godderis. 2017. Dietary and supplemental maternal methyl-group donor intake and cord blood DNA methylation. Epigenetics 12:1. https://doi.org/10.1080/15592294.2016.1257450.

Petry, A., M. Weitnauer, and A. Görlach. 2010. Receptor activation of NADPH oxidases. Antioxid. Redox Signal. 13:467-487. https://doi .org/10.1089/ars.2009.3026.

Pfaffl, M. W. 2001. A new mathematical model for relative quantification in real-time RT-PCR. Nucleic Acids Res. 29:e45. https://doi .org/10.1093/nar/29.9.e45.

Riedmaier, I., M. Bergmaier, and M. W. Pfaffl. 2010. Comparison of two available platforms for determination of RNA quality. Biotechnol. Biotechnol. Equip. 24:2154-2159. https://doi.org/10.2478/ V10133-010-0074-7.

Rinaldi, M., P. Moroni, M. J. Paape, and D. D. Bannerman. 2008. Differential alterations in the ability of bovine neutrophils to generate extracellular and intracellular reactive oxygen species during the periparturient period. Vet. J. 178:208-213. https://doi.org/10 1016/j.tvjl.2007.07.030

Rosen, H., and S. J. Klebanoff. 1976. Chemiluminescence and superoxide production by myeloperoxidase-deficient leukocytes. J. Clin. Invest. 58:50-60.

Shuster, D. E., E. K. Lee, and M. E. Kehrli Jr.. 1996. Bacterial growth, inflammatory cytokine production, and neutrophil recruitment during coliform mastitis in cows within ten days after calving, compared with cows at midlactation. Am. J. Vet. Res. 57:15691575 .

Siemsen, D. W., I. A. Schepetkin, L. N. Kirpotina, B. Lei, and M. T. Quinn. 2007. Neutrophil isolation from nonhuman species. Methods Mol. Biol. 412:21-34. https://doi.org/10.1007/978-1-59745 $-467-43$.

Stevens, M. G. H., L. Peelman, B. De Spiegeleer, A. Pezeshki, G. R. Van De Walle, L. Duchateau, and C. Burvenich. 2011. Differential gene expression of the toll-like receptor-4 cascade and neutrophil function in early- and mid-lactating dairy cows. J. Dairy Sci. 94:1277-1288. https://doi.org/10.3168/jds.2010-3563.

Stothard, P. 2000. The Sequence Manipulation Suite: JavaScript programs for analyzing and formatting protein and DNA sequences. Biotechniques 28:1102-1104.

Untergasser, A., H. Nijveen, X. Rao, T. Bisseling, R. Geurts, and J. A. M. Leunissen. 2007. Primer3Plus, an enhanced web interface to Primer3. Nucleic Acids Res. 35:W71-W74. https://doi.org/10 $.1093 /$ nar/gkm306

Van Poucke, M., X. Boulougouris, B. De Spiegeleer, C. Burvenich, L. Duchateau, and L. Peelman. 2017. An optimized strategy for cloning-based locus-specific bisulfite sequencing PCR. bioRxiv. https:/ /doi.org/10.1101/239566.

Van Poucke, M., and L. Peelman. 2017. Flexible, multi-use, PCRbased nucleic acid integrity assays based on the ubiquitin $\mathrm{C}$ gene. bioRxiv. https://doi.org/10.1101/168195.

Van Werven, T., E. N. Noordhuizen-Stassen, A. J. Daemen, Y. H. Schukken, A. Brand, and C. Burvenich. 1997. Preinfection in vitro chemotaxis, phagocytosis, oxidative burst, and expression of CD11/CD18 receptors and their predictive capacity on the outcome of mastitis induced in dairy cows with Escherichia coli. J. Dairy Sci. 80:67-74.

Vandeputte-Van Messom, G., C. Burvenich, E. Roets, A. M. MassartLeën, R. Heyneman, W. D. Kremer, and A. Brand. 1993. Classification of newly calved cows into moderate and severe responders to experimentally induced Escherichia coli mastitis. J. Dairy Res. 60:19-29.

Vandesompele, J., K. De Preter, F. Pattyn, B. Poppe, N. Van Roy, A. De Paepe, and F. Speleman, 2002. Accurate normalization of real-time quantitative RT-PCR data by geometric averaging of multiple internal control genes. Genome Biol. 3:0034.

Vangroenweghe, F., L. Duchateau, and C. Burvenich. 2004. Moderate inflammatory reaction during experimental Escherichia coli mastitis in primiparous cows. J. Dairy Sci. 87:886-895. https://doi.org/ 10.3168/jds.S0022-0302(04)73233-6.

Vangroenweghe, F., I. Lamote, and C. Burvenich. 2005. Physiology of the periparturient period and its relation to severity of clinical mastitis. Domest. Anim. Endocrinol. 29:283-293. https://doi.org/ 10.1016/j.domaniend.2005.02.016.

Verbeke, J., M. Van Poucke, L. Peelman, and S. De Vliegher. 2015. Differential expression of CXCR1 and commonly used reference genes in bovine milk somatic cells following experimental intramammary challenge. BMC Genet. 16:40. https://doi.org/10.1186/ s12863-015-0197-9.

Wojdacz, T. K., L. Hansen, and A. Dobrovic. 2008. A new approach to primer design for the control of PCR bias in methylation studies. BMC Res. Notes 1:54. https://doi.org/10.1186/1756-0500-1-54.

Yates, A., W. Akanni, M. R. Amode, D. Barrell, K. Billis, D. Carvalho-Silva, C. Cummins, P. Clapham, S. Fitzgerald, L. Gil, C. G. Giron, L. Gordon, T. Hourlier, S. E. Hunt, S. H. Janacek, N. Johnson, T. Juettemann, S. Keenan, I. Lavidas, F. J. Martin, T. Maurel, W. McLaren, D. N. Murphy, R. Nag, M. Nuhn, A. Parker, M. Patricio, M. Pignatelli, M. Rahtz, H. S. Riat, D. Sheppard, K. Taylor, A. Thormann, A. Vullo, S. P. Wilder, A. Zadissa, E. Birney, J. Harrow, M. Muffato, E. Perry, M. Ruffier, G. Spudich, S. J. Trevanion, F. Cunningham, B. L. Aken, D. R. Zerbino, and P. Flicek. 2016. Ensembl 2016. Nucleic Acids Res. 44:D710-D716. https://doi.org/10.1093/nar/gkv1157. 